\title{
Determination of Heavy Metal Distributions in the Green-Lipped Mussel Perna viridis as Bioindicators of Heavy Metal Contamination in the Johore Straits and Senggarang, Peninsular Malaysia.
}

\begin{abstract}
In this study, the patterns of the distributions and redistributions of heavy metals in the different soft tissues of Perna viridis were determined. Crystalline style and muscle were found to be sensitive organs to pollution as evidenced by total disturbances in the patterns of metal occurrences. The present findings confirmed the use of different soft tissues as an effective way of monitoring the status of metal pollution in tropical coastal waters. Therefore, the distribution of metals in different parts of $\mathrm{P}$. viridis is proposed as a good indicator of metal pollution in tropical coastal waters.
\end{abstract}

Keyword: Perna Viridis; Heavy metal; Tropical coastal water; distribution; Redistribution; Different soft tissues. 